\title{
Beneficiaries of A Place: Whose Life Is Better?'
}

\author{
Kirill L. Rozhkov \\ (iD) https://orcid.org/0000-0003-1765-1611 \\ Higher School of Economics \\ Faculty of Management \\ e-mail: natio@bk.ru
}

\section{Konstantin Khomutskii}

(iD) https://orcid.org/0000-0001-5929-8858

Higher School of Economics

School of Foreign Languages

e-mail: khomutskiykonst@gmail.com

\section{Abstract}

The paper shows relationships between the characteristics of residents and the places, where they live. A combination of three criteria of place attractiveness (retention and attraction, conditions for natural growth, and settling) was chosen to classify places, and profiles of their beneficiaries on the theoretical level. The results of the empirical study partially confirm the developed theoretical typologies. Two methods to segment place market are equal only if expectations of population are constant. Study results allow place marketers to identify emerging shifts in the structure of beneficiaries of specific places and predict their further evolution.

Keywords: resident, beneficiary, market segment

1 This work is an output of a research project implemented as part of the Research Program of the Faculty of Business and Management at National Research University - Higher School of Economics. 


\section{Introduction}

Cities, towns and even villages have to compete for the inhabitants, investors, and visitors to meet new global challenges. An answer to the question "How can a concrete place attract the target residents?' has become the key 'know-how' of a place to succeed in this competition.

The issue of preferences of the main population groups, regarding place attributes, has been an important area of emphasis in urban planning research over the past two decades. Differences in environmental preferences between different population groups and classes have generated considerable interest in the planning literature (Stamps; Regan and Horn; Niedomysl). Studies on demographic, socioeconomic, and geographic components of the preferences have contributed to contemporary understanding of residential behaviour (Lindberg et al.; Dokmeci and Berkoz; Niedomysl; and Kim et al.).

Any place is a complex combination of place attributes (place characteristics, facilities, etc.). This approach was reflected by Ashworth and Voogd; Ulaga et al.; Walters. It is also difficult or impossible to change such place attributes as geographical location, climate, the layout of streets, history, and, in some ways, the habits and customs of citizens. These facts make researchers evaluate residential attitudes toward both separate place attributes and their combinations or profiles using multiattribute approaches and methods (Van Poll; Molin).

In addition, residential preferences have considerable influence on the satisfaction of migrants, tourists and the existing inhabitants, which, in turn, is a determining factor in place marketing and place branding. Considering place as a complex product and the above-mentioned groups as place customers (or target groups of place marketing), it becomes particularly significant to distinguish crucial place attributes that meet preferences of the most valuable groups and largely determine their perceptions of place image and attitudes toward place as a whole (Zenker et al.).

Meanwhile, until now one important issue regarding the practical application of this research has not found a definitive interpretation. On the one hand, the marketing strategy of a place has to be segmented as a marketing strategy of a firm to compete successfully (i.e. to attract valuable residents - Kotler). On the other hand, the concept of a plurality of target groups in place marketing (Ashworth and Voogd) and the concept of undifferentiated marketing (Ward) are in obvious contradiction with this idea. Local authorities and other local stakeholders will inevitably experience difficulties with the development of a place marketing strategy that has to be segmented and coordinated simultaneously with the interests of a broad range of place consumers. In other words, it has been uncertain, what value (value of a place or value of a customer) should underlie the place marketing activities. 
The assumption that the creative class is the most valuable (and external, as a rule) target group (Zenker) reflects an approach in place marketing research which could be called "customer-value". At the same time, it is necessary to learn more about the typical preferences of the population groups which already inhabit specific places. The approach of Ge and Hokao, who propose the concept of residential lifestyles and identify empirically four types of residential preferences, can be considered a "place-value" one.

Parker et al. developed this approach and concluded that the clustering of people with similar spatial preferences concurrently means the clustering of places with similar geographic and socio-cultural attributes that are of particular significance for geography and urban sociology. Besides, from our point of view, a list of probable applications of this idea is not limited to these sciences. A classification of places by residential preferences could be a valuable tool for place marketing analysis because it can obviously help place marketers to reveal and describe places as complex products like any product range in the general field of marketing. In addition, such a classification could allow place marketers to determine accurately the target groups whose diversity, indeed, is inherent in the large proportion of real places and inhibits marketing activities in the interests of any one group. That is, place marketing strategy could be developed in the frame of standardised methodology, not as a summarised experience of different cities and towns.

Meanwhile, the theory of place market segmentation (theoretical classifications and typologies, as well as answers to this question on a theoretical level) is one of the less investigated issues in place marketing. And empirical findings on the relationships between place product attributes and place consumers mentioned above can be applied only in special cases. In particular, the diversity of existing and probable target groups, which can be observed in real cities and places, have not yet been reflected in place marketing theory and methodology.

\section{Research concept}

Based on the discussion above, there are several questions that will serve as a starting point of this research. The answer to the practical question "How can a specific place attract the desired resident groups?" that was asked at the beginning of this paper, requires stating two theoretical questions: "What residents are considered valuable by different places?" "What type of places can attract what kind of residents?" (or "What kind of residents prefer what type of places?") Only having these two questions answered, it will be possible to determine how a specific place should be changed in order to attract residents that are considered as valuable and, thus, give an answer to the first question. 
In our previous study (Rozhkov, "Segmentation") profiles (combinations) of expected demographic indicators of five Russian towns (expected demographic profiles) and profiles of their attributes (towns' profiles) were compared using the typological method. This paper is aimed at comparing demographic profiles of towns to the profiles of their main beneficiaries.

It is necessary to emphasise that the use of the term "target group" is based on the assumption of real marketing activities whose goals are to meet the preferences of a special group of the population. However, place marketing may not be a particularly common tool of public policy, especially in Russia. That is, a place can be managed in the interests of a certain de facto group, but this policy may be not announced. Consequently, it seems essential to use the term "beneficiary of a place" and define it as a group of the population whose preferences are most exactly met by existing place attributes. The following statements underlie the investigation.

1. Certain population groups have preferences regarding the range and quality of place attributes.

2. A specific place has attributes of specific range and quality.

3. Therefore, this place only meets the interests of those population groups whose preferences are the closest to its attributes.

4. The range and the quality of place attributes determine residents' behaviour as the place customers (demographic behaviour of local population as a whole), which, in turn, can be considered as the main characteristic of a place as a product to be marketed.

5. Each type of place is oriented to the satisfaction of place beneficiaries' needs, i.e. beneficiaries demonstrate the most significant satisfaction among other population groups.

6. Consequently, every specific place belongs to a certain type of place and very rarely can fulfil the needs of all residents (or make their lives better). That is, this place hardly ever meets all the criteria of place attractiveness.

7. Finally, the type of place and the profile of beneficiaries of this place are related. In other words, beneficiaries' attitudes towards a place differ from both those of the rest of the population of this place and those of other places. And it is possible to distinguish a beneficiary of each type of place from those who find the place less valuable.

The conceptual base of this research is the heuristic monothetic 3-dimensional typology of places (table 1) and the classification of their distinctive characteristics (Rozhkov, "Tselevye”; Rozhkov, "Segmentation”). 
Table 1. The heuristic monothetic 3-dimensional typology of places

\begin{tabular}{|c|c|c|c|}
\hline \multirow{2}{*}{$\begin{array}{l}\text { Type of } \\
\text { place }\end{array}$} & \multicolumn{3}{|c|}{ A combination of criteria for attractiveness of place to residents } \\
\hline & $\begin{array}{l}\text { retention and } \\
\text { attraction }\end{array}$ & natural growth & settling \\
\hline 1 & - & - & - \\
\hline 2 & - & - & + \\
\hline 3 & - & + & - \\
\hline 4 & + & - & - \\
\hline 5 & + & + & - \\
\hline 6 & + & - & + \\
\hline 7 & + & + & + \\
\hline 8 & - & + & + \\
\hline
\end{tabular}

This paper will discuss whether it is possible to describe the beneficiaries of these nominal places on a theoretical level. If so, then the developed typology could be used as a tool for the segmentation of specific places.

It is possible to assume that the following types of places fulfil the needs of the following population groups or, in other words, these population groups show the highest level of satisfaction with the following places (Table 2).

In other words, it may be suggested that only identifying the type of place, which a specific place belongs to, allows place marketers to understand whose life is better in this town. Alternatively, by classifying the demographic characteristics of the most satisfied people, it becomes possible to establish the belonging of a specific place to a certain type and vice versa.

\section{Data and methods}

To examine the hypothesis a street survey of residents was conducted (2,00o people aged 17 and older in five Karelian towns were surveyed).

Based on the results of the survey, a focus group was formed. The focus group consisted of authority representatives, members of the public and non-commercial organisations of surveyed towns. The participants were asked to comment on the results of the survey and in particular those ones which did not approve the hypothesis mentioned above. We have also used local statistical data.

There is some evidence to suggest that the benefits of a place are subjective, which can be better evaluated by residents than anybody else. As each place is mostly oriented to fulfil the needs of place beneficiaries, they are those who demonstrate the most significant level of satisfaction among other population groups. 


\begin{tabular}{|c|c|c|c|c|c|c|c|c|}
\hline$\frac{n}{\frac{n}{5}}$ & 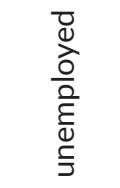 & 这 & 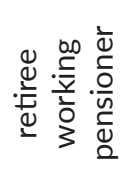 & $\frac{\stackrel{D}{D}}{\frac{0}{0}}$ & 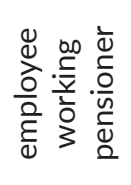 & 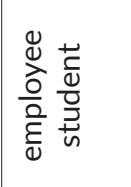 & 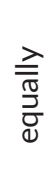 & 交 \\
\hline 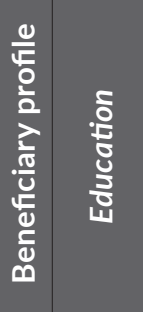 & 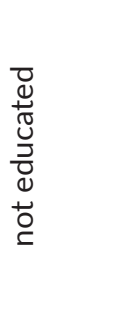 & 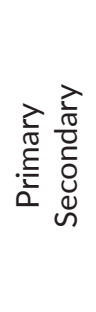 & 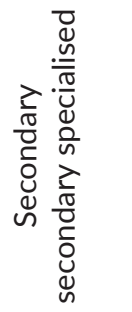 & 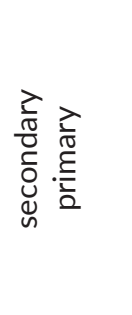 & 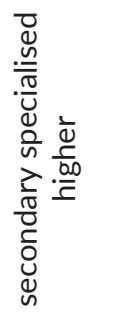 & 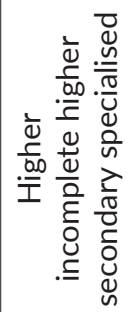 & 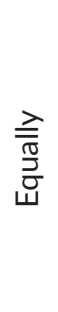 & 主 \\
\hline 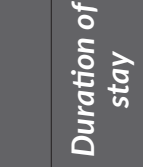 & 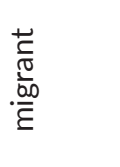 & 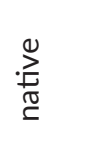 & 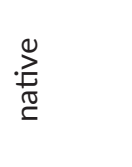 & $\begin{array}{l}\frac{\vec{C}}{\frac{0}{0}} \\
\frac{.00}{E} \\
\frac{.00}{E}\end{array}$ & 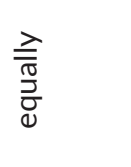 & $\frac{\gtrsim}{\overline{\bar{T}}}$ & $\frac{\gtrsim}{\overline{\bar{T}}}$ & 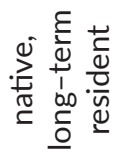 \\
\hline 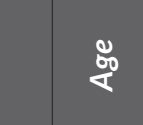 & 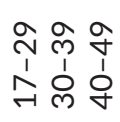 & $\begin{array}{l}\text { nn } \\
\text { in } \\
\bar{d} \\
0\end{array}$ & 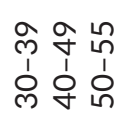 & 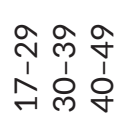 & 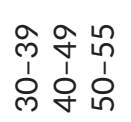 & 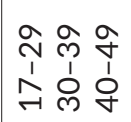 & $\frac{\gtrsim}{\overline{\frac{\pi}{J}}}$ & 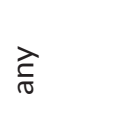 \\
\hline ڤั & $\frac{\frac{\varrho}{\sigma}}{\stackrel{\varepsilon}{\varepsilon}}$ & $\frac{\overrightarrow{\bar{T}}}{\frac{\pi}{\sqrt{d}}}$ & 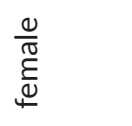 & $\frac{\frac{U}{\pi}}{\stackrel{\Xi}{\varepsilon}}$ & $\frac{\lambda}{\overline{\bar{T}}}$ & $\frac{\gtrsim}{\overline{\bar{J}}}$ & $\frac{\gtrsim}{\frac{\pi}{D}}$ & $\underset{⿱ 亠}{\vec{\sigma}}$ \\
\hline 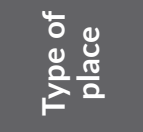 & $\begin{array}{c}T \\
1 \\
\end{array}$ & $\begin{array}{c}T \\
1 \\
\frac{1}{N}\end{array}$ & $\begin{array}{l}T \\
+\frac{1}{m}\end{array}$ & $\begin{array}{l}T \\
1 \\
+ \\
y\end{array}$ & 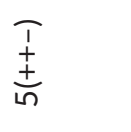 & $\begin{array}{l}7 \\
1 \\
\pm \\
0\end{array}$ & 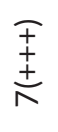 & $\begin{array}{l}\frac{7}{+} \\
+ \\
\frac{1}{\infty}\end{array}$ \\
\hline
\end{tabular}


To build empirical profiles of beneficiaries, data on the level of residential satisfaction with each surveyed town, as a whole, and demographic characteristics of the respondents were collected and summarised. The included question was "How would you rate your town (on a 5-point scale)?" In addition, questions about the following demographic characteristics of the respondents were also asked: sex, age, duration of stay, education, social status. Then all satisfied respondents (who gave marks " 4 " or " 5 " to their town) were grouped according to these characteristics, and proportions of these groups in the total number of satisfied respondents in each town were calculated.

Each specific town was classified by three demographic indicators below (Table 3).

Table 3. Indicators for attractiveness of place to residents

Criteria for attractiveness of place to residents

\begin{tabular}{|l|l|}
\hline 1. retention & expected departure \\
\hline 2. natural growth & expected birth rate \\
\hline 3. settling & $\begin{array}{l}\text { difference of expected general birth rate and expected } \\
\text { departure of natives }\end{array}$ \\
\hline
\end{tabular}

Data on reproduction and departure expectations of respondents were collected to evaluate these indicators. Two questions included in the questionnaire were: "Would you move to another place if it were possible?" and "Are you planning to have a child (or another child) in the near future?"

To compute the indicators of expected departure, the frequency of the answers to these questions relative to the number of all respondents in each town was calculated. Following this, an average value of this relative frequency for all surveyed towns was subtracted from the value of each town. With regard to expected birth rate, the same calculations were done; however, only the childbearing-age women's answers were counted, and the results were first related to the total number of these women in each surveyed town.

To compute the indicators of settling difference of expected general birth rates and the expected emigration of natives for each town was calculated. Then an average value of this difference for all surveyed towns was subtracted from the value of each town.

Each indicator of attractiveness is a binary variable "+" (yes) or “-"(no), whether the relative frequency of the answers to the questions mentioned above for each town was more or less its average value. The combinations of the values of these three indicators showed the empirical types of places the surveyed towns belong to. 
Further, the number of coincidences between theoretical and empirical beneficiaries' characteristics was calculated, and the closest type of place was revealed for each surveyed town.

Finally, the empirical type of place and the one that was identified as the closest to empirical beneficiaries' profiles were compared to each surveyed town to check the hypothesis.

\section{Results}

The combination of values of three expected demographic indicators for each town pointed to its empirical type of place (Table 4 ). The positive values of the first indicator were interpreted as the absence of the criteria of retention and vice versa.

Table 4. Empirical types of places

\begin{tabular}{|c|c|c|c|c|}
\hline \multirow[b]{2}{*}{$\begin{array}{l}\text { Surveyed } \\
\text { town }\end{array}$} & \multicolumn{3}{|c|}{ Indicators for attractiveness of place to residents } & \multirow[b]{2}{*}{$\begin{array}{l}\text { Empirical } \\
\text { type of } \\
\text { place }\end{array}$} \\
\hline & $\begin{array}{l}\text { relative } \\
\text { expected } \\
\text { departure }\end{array}$ & $\begin{array}{l}\text { relative } \\
\text { expected } \\
\text { birth rate }\end{array}$ & $\begin{array}{l}\text { difference of relative expected } \\
\text { general birth rate and relative } \\
\text { expected departure of natives }\end{array}$ & \\
\hline Pudozh & $22 \%$ & $0 \%$ & $-18 \%$ & $3(-+-)$ \\
\hline Segezha & $65 \%$ & $-5 \%$ & $-19 \%$ & $1(---)$ \\
\hline Kondopoga & $-17 \%$ & $7 \%$ & $18 \%$ & $7(+++)$ \\
\hline Sortavala & $-6 \%$ & $-5 \%$ & $5 \%$ & $6(+-+)$ \\
\hline Olonets & $-8 \%$ & $4 \%$ & $15 \%$ & $7(+++)$ \\
\hline
\end{tabular}

Demographic structures of satisfied residents for each surveyed town are presented in Table 5 .

The figures show some similarities in the empirical profiles of beneficiaries. For instance, social status is the demographic characteristic of satisfied people that is common for all towns. Employees have the largest proportion among those respondents who gave marks " 4 " or " 5 " to their towns in comparison to other social groups. Four out of five towns are attractive for people with secondary specialised education and the same number mostly fulfils the needs of the residents of both sexes. This profile points to the type 5 of the typology which is the conceptual base of the study.

However, more particular conclusions can be made if both similarities and differences between towns are analysed and, especially, demographic characteristics of satisfied groups of not only between investigated towns as within them are compared. 
Both the profile of beneficiaries and the combination of values of place attractiveness indicators of Sortavala point to the same type 6. Focus group data meet the trends revealed by the survey analysis. The only clarification that is needed is the one regarding the description of beneficiaries of this type on a theoretical level. Any business or trade places, not only megacities, can match this theoretical type. Sortavala is such a place with well-developed cross-border trade and with cultural and other links to Finland. Young residents can fulfil their aspirations, do not strive to move out, and seem to behave in line with European stereotypes of childbearing, having one or two children in a family.

Pudozh's typical beneficiary is a 55 years-old (38\% of satisfied respondents) man or woman who was born here $(76 \%)$. These figures could be interpreted as signs of the $2^{\text {nd }}$ type, but education points to the $3^{\mathrm{d}}$ type and the social status of the beneficiaries belongs to the $5^{\text {th }}$ one. The place type number of Pudozh, revealed empirically, is the $3^{\mathrm{d}}$. The expected birth rate in Pudozh coincides with the average value for all surveyed towns and gives reason to assume that the town probably moves from the $2^{\text {nd }}$ to the $3^{\mathrm{d}}$ type. That is, the demographic expectations of the people are somewhat better than their real life in the town, which beneficiaries rated. Additional information obtained from focus group showed that some new settlers have begun to move in. However, we have no sufficient figures that prove that they are those who support the relative expected birthrate.

Segezha and Kondopoga have the same profiles of beneficiaries which include primarily features of the $5^{\text {th }}$ type of place. Focus group and local statistical data also indicate the industrial profile of both towns. However, there are apparent discrepancies between the profile of beneficiaries and empirical type of place of each town.

Residents of Kondopoga demonstrate comparatively low expected departure and young people are optimistic. This optimism (18\%) is more obvious than in the case of Pudozh's women, who showed expected childbearing (o\%). It means that there are sufficient prerequisites for young people to become beneficiaries, although they have not become them yet.

On the contrary, residents of Segezha are highly pessimistic in the worst values of all three indicators for attractiveness. Therefore, probable future shifts in the structure of beneficiaries will be extremely unfavourable if the residents' expectations transform into behaviour.

Olonets is the most difficult case of all surveyed towns for interpretation in terms of the research concept. The characteristics of the beneficiaries can be matched to different theoretical types of places. However, a more interesting fact is that Olonets beneficiaries seem to belong to those types which are not adjacent in typology so that the town cannot be considered as moving from one type to another. 


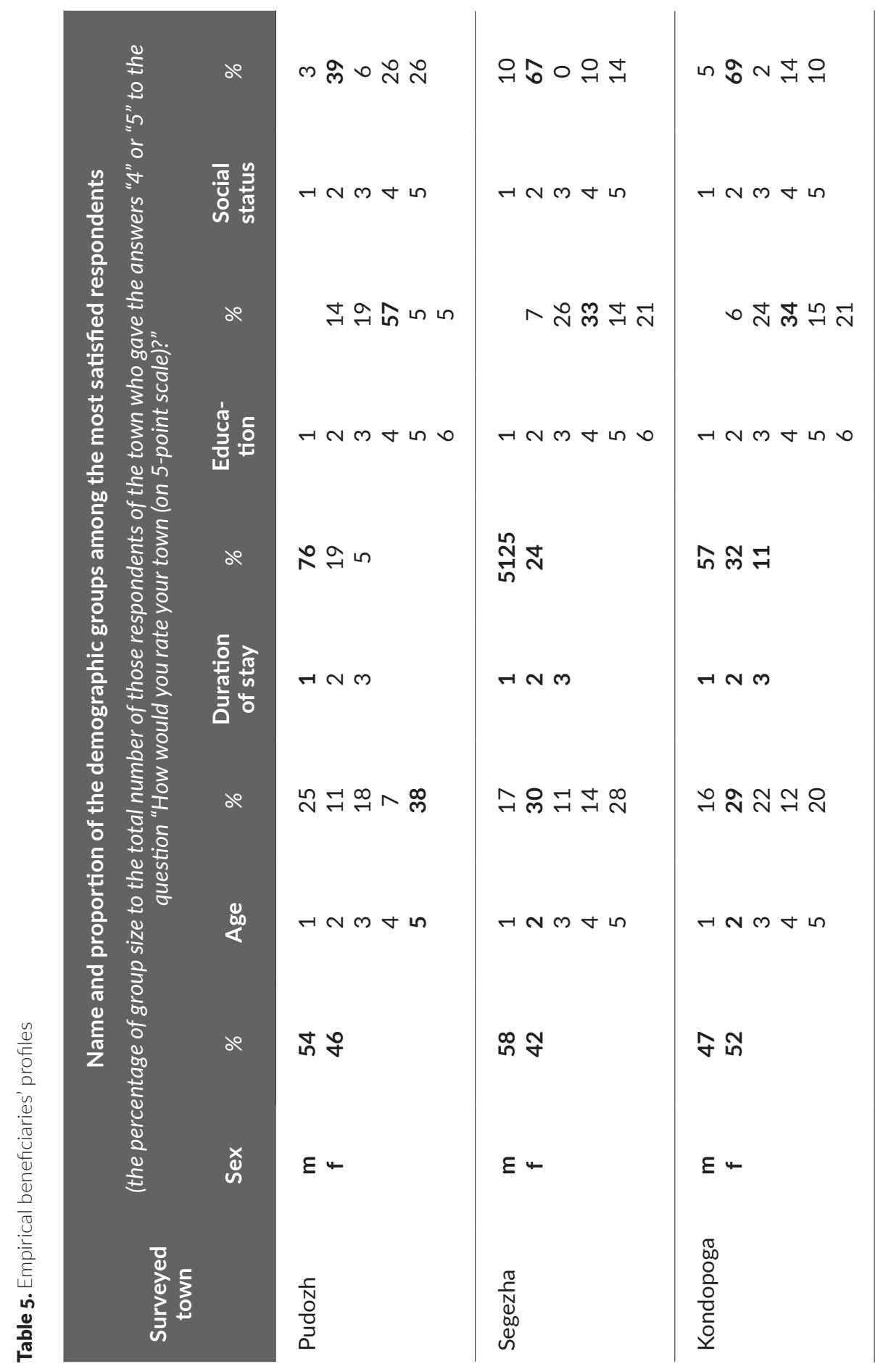




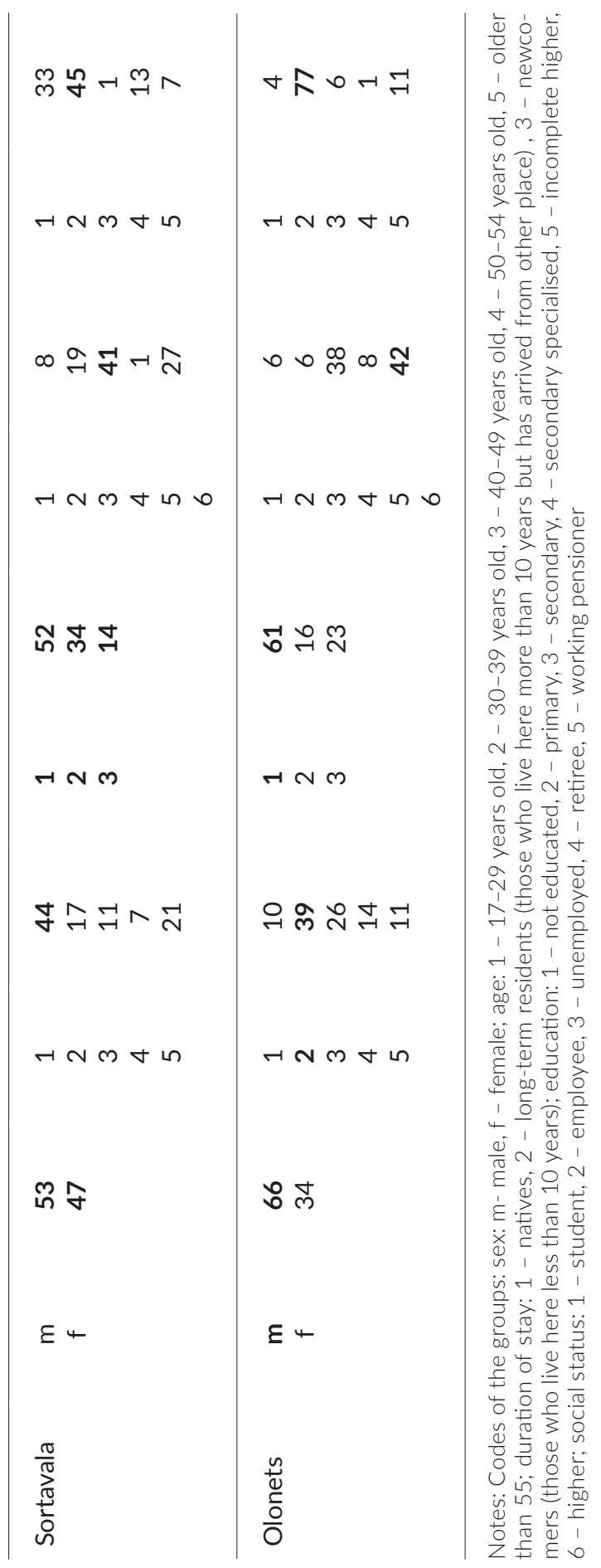


Table 6 shows the number of coincidences between empirical (see Table 4) and theoretical (see Table 2) profiles of beneficiaries and the closest theoretical types of places for each surveyed town.

Table 6. Correspondence between empirical beneficiaries' profiles and theoretical types of places

\begin{tabular}{|c|c|c|c|c|c|}
\hline \multicolumn{5}{|c|}{$\begin{array}{c}\text { Number of coincidences between theoretical and empirical } \\
\text { beneficiaries' profiles }\end{array}$} & \multirow{2}{*}{$\begin{array}{l}\text { The } \\
\text { theoretical } \\
\text { type of } \\
\text { place }\end{array}$} \\
\hline Pudozh & Segezha & Kondopoga & Sortavala & Olonets & \\
\hline 0 & 0 & 0 & 1 & 1 & $1(---)$ \\
\hline 3 & 1 & 1 & 1 & 1 & $2(--+)$ \\
\hline 2 & 2 & 2 & 0 & 3 & $3(-+-)$ \\
\hline 0 & 2 & 2 & 2 & 2 & $4(+--)$ \\
\hline 2 & 4 & 4 & 3 & 3 & $5(++-)$ \\
\hline 1 & 2 & 2 & 4 & 1 & $6(+-+)$ \\
\hline 1 & 2 & 2 & 2 & 0 & $7(+++)$ \\
\hline 1 & 1 & 1 & 1 & 1 & $8(-++)$ \\
\hline
\end{tabular}

The comparisons between the closest theoretical (Table 6) and empirical (Table 4) types of places for each town allows us to conclude that the hypothesis of empirical study was supported in Sortavala, partially supported in Pudozh and not supported in three remaining cases.

\section{Discussion}

If the applications of two developed theoretical typologies - typology of places and beneficiaries - are compared as a whole, it cannot be stated definitely that there is a consistency between them at the empirical level. That is, the theoretical model of place market segmentation should be corrected in order to typify places and their beneficiaries more adequately.

The first point to be made is that demographic expectations of residents are not always the same as their attitude toward a place as a whole. In other words, the expected behaviour can be both better and worse than a real life in a specific place. Consequently, two methods to segment place market - by both attitude of beneficiaries and expected behaviour or population as a whole - are equal only if expectations of the population are constant. Otherwise, a discrepancy arises and this makes the theoretical model of segmentation unsuitable because population expectations and profiles of beneficiaries can be unrelated (as the cases of Segezha and Kondopoga show). 
It is more reasonable to conclude that the profiles of beneficiaries should include not only objective demographic characteristics but also variables of expectations and behaviour to segment residents as accurately as places of their residence.

In addition, it would be useful to clarify the definitions of the $1^{\text {st }}$ and the $7^{\text {th }}$ types of places in the typology. They have a special place in it, reflecting extreme negative (Segezha) or positive (Kondopoga and Olonets) expectations of the population in general and, at the same time, as the other types, they are mostly connected with expectations of particular groups.

Another convenient way of resident segmentation can be worked out if we compare investigated profiles of beneficiaries to empirical statistical data rather than predicted behaviour.

Nevertheless, the approach represented in this paper is valuable by itself because it allows place marketers to identify emerging shifts in the structure of beneficiaries of specific places and predict their further evolution. Indeed, any difference between a profile of beneficiaries and type of place could be interpreted as a probable change of the most satisfied group in the near future. It can be assumed, for instance, that Pudozh might be more attractive for women of childbearing age, Kondopoga could succeed in the retention of the young cohort, and Segezha will lose attractiveness to any internal population group.

Finally, to resolve the problem of contradictions in empirical profiles of the most satisfied residents (for example, Olonets' residents) it is necessary to change the polythetic typology to a monothetic one. That is, each theoretical profile should be completely different and homogenous to identify exactly empirical data on residents' characteristics.

\section{Conclusion}

The present article provides the basis for segmentation of residents as place users. Segmentation is becoming a topical issue while considering the needs to develop marketing and branding strategies aimed at target groups, rather than those strategies, dealing with the improvement of local living standards and welfare in general.

In other words, the task to enhance places for the benefit of people is a multi-criteria one. In practice, there appear some specific places, where the needs of certain target groups have to be satisfied. Moreover, the specific nature of residents as place users implies that the place, somehow, has already been used by them before place branding managers have decided to develop it in one way or another.

Therefore, place development management is connected with determining not only future benefits for target groups but also those which have already been assigned to all residents. In this regard, introducing the concept of "beneficiaries of 
a place," as well as revealing its (concept's) demographic and behavioural profile, is an important challenge for place marketing and place branding research.

The current paper represents the first step in this direction, i.e. we have investigated the link between characteristics of residents and place. The authors argue that the typology of places, used in the research, makes it viable to shift the focus from already studied spatial preferences of certain groups towards methodological development of segmentation in place marketing.

\section{Works Cited}

Ashworth, G. J., and H. Voogd. "Marketing the City: Concepts, Processes and Dutch Applications." Town Planning Review 59.1. (1988): 65-79.

Dokmeci, V., et al. "Residential-location Preferences According to Demographic Characteristics in Istanbul." Landscape and Urban Planning 48 (2000): 45-55.

Ge, J., and K. Hokao. "Research on Residential Environmental Evaluation of Local Cities Considering Regional Characteristic and Personal Residential Preference - a Case Study of Saga City, Japan.” J. Environ. Sci. 16.1 (2004): 138-144.

Kim, T., et al. "Life Cycle and Environmental Factors in Selecting Residential and Job Locations." Housing Studies 20.3 (2005): 457-473.

Kotler Ph., et al. Marketing Places: Attracting Investment, Industry and Tourism to Cities, States and Nations. New York: The Free Press, 1993.

Lindberg, E., et al. "Residential-location Preferences across the Life Span." Journal of Environmental Psychology 12.2 (1992): 187-198.

Molin, E., et al. "Group-based versus Individual-based Conjoint Preference Models of Residential Preferences: A Comparative Test.” Environment and Planning A 31.11 (1999): 1935-1947.

Niedomysl, T. "Residential Preferences for Interregional Migration in Sweden: Demographic, Socioeconomic, and Geographical Determinants.” Environment and Planning A 40.5 (2008): 1109-1131.

Parker, S., et al. "Class Places and Place Classes Geodemographics and the Spatialization of Class.” Information, Communication and Society 10.6 (2007): 902-921.

Regan, C. L., and S. A. Horn. "To Nature or not to Nature: Associations between Environmental Preferences, Mood States and Demographic factors." Journal of Environmental Psychology 25.1 (2005): 57-66.

Rozhkov, K. L. "Segmentation of Inhabitants in Place Marketing: The Case of Karelian Towns." Higher School of Economics Research Paper No. WP BRP 02/MAN/2012. (2012). Retrieved http://ssrn.com/abstract=2071977.

Rozhkov K. L. Tselevye gruppy, funktsii i izmeriteli rezul'tativnosti vnutrennego marketinga mest (stat'ya) // Problemy sovremennoi ekonomiki 4 (2011): 232-235. 
Stamps III, A. E. "Demographic Effects in Environmental Aesthetics: A Metaanalysis." Journal of Planning Literature 14.2 (1999): 170-174.

Ulaga, W., et al. "Plant Location and Place Marketing: Understanding the Process from the Business Customer's Perspective." Industrial Marketing Management 31.5 (2002): 393-401.

Van Poll, R. "The Perceived Quality of the Urban Residential Environment: A Multiattribute Evaluation". (1997). Retrieved http://www.ub.rug.nl/eldoc/dis/science/ h.f.p.m.van.poll.

Walters, W. H. "Assessing the Impact of Place Characteristics on Human Migration: The Importance of Migrants' Intentions and Enabling Attributes." Area 32.1 (2000): 119-123.

Ward, S. V. Selling Places: The Marketing and Promotion of Towns and Cities 18502000. London: Spon Press, 2004.

Zenker, S. "Who's your Target? The Creative Class as a Target Group for Place Branding." Journal of Place Management and Development 2.1 (2009): 23-32.

Zenker, S. et al. "Development and Implementation of the Citizen Satisfaction Index (CSI): Four Basic Factors of Citizens' Satisfaction.” Research Papers on Marketing and Retailing, 39 (2009): 1-19.

Рожков К. Л. Целевые группы, функции и измерители результативности внутреннего маркетинга мест (статья)// Проблемы современной экономики, 2011. № 4, cc. 232-235.

Kirill Rozhkov - Professor at the Faculty of Business and Management in the Higher School of Economics, Moscow, Russia. He is also a Fellow of the Institute of Place Management (Manchester, UK). His research interests lie in place marketing, place management, and place branding. Kirill Rozhkov has published about 70 scientific papers in different international and Russian journals on economics and management.

Konstantin Khomutskii - Associate Professor at the National Research University Higher School of Economics. His areas of research interests include cognitive linguistics, sociolinguistics, pragmatics, semantics and conceptualization, place marketing and branding. He is currently involved in a number of international cross-disciplinary projects, which deal with the application of linguistic methods to various studies in marketing, branding, and psychology. 